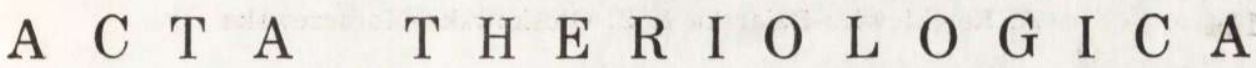

VOL. $20,9: 113-122$.

April, 1975

Agnieszka R E W K I E W I C Z - D Z I A R S K A

\& Zofia GŁOSKOW SKA-MORACZEWSKA

\section{Diurnal Rhythm of Selected Haematological Values in the Central and Peripheral Blood Circulation of the Rabbit}

[With 2 Table \& 3 Figs.]

\begin{abstract}
Cyclic changes in the red cell system, suggesting the existence of a diurnal rhythm, have been found in 47 mongrel rabbits. The diurnal fluctuations occur in the blood of both peripheral and central vessels.

The haemoglobin level of the blood in the marginal ear vein is significantly higher than that in the posterior vena cava. No significant differences have been found between the haematocrit value of the blood in the central vessels and that in the peripheral vessels.
\end{abstract}

\section{INTRODUCTION}

There are numerous examples of diurnal rhythms and seasonal cycles in the animal kingdom (B ullough, 1947; Kleitman, 1949; Harker 1958; B a ranski, et al., 1972 a). Rhythmic changes in the function of the haemopoietic system and in the composition and picture of blood are known phenomena. B a $\mathrm{r}$ ańs ki et al., (1972 b) showed a distinct mitotic rhythm with a peak at 8 p.m. in the haemopoietic system of guinea pigs, light being an active synchronizer of mitoses in this system. Halberg \& Viss cher (1950) detected that physiological eosinopenia occurs in the mouse, unexposed to stress factors, in the night. Studying the diurnal rhythm of the number of eosinophiles in man, Donato \& S t r u mia (1952) demonstrated that it attains its lowest level at noon and a peak in the night. Rhythmic diurnal changes in the number of reticulocytes and the rate of their maturation in rats were found by Goldeck \& Stoffregen (1952). The highest values were recorded in the evening and a minimum in the night. This rhytm seems to be endogenous. Delaney (1960) reported the presence of diurnal physiological fluctuations in the haemoglobin level in man. It dropped between 6 a.m. and 10 p.m. and rose during sleep. Fox \& L a ird (1970) carried out a study of changes in the haematological values in the diurnal rhythm by determining the numbers of erythrocytes and leucocytes, the haematocrit value, and the haemoglobin level in the blood from the ear vein in the rabbit. The highest haematocrit value, haemoglobin level and number of erythrocytes were found between 8 a.m. and the noon, and the lowest ones in the afternoon and evening. 
The haematological values at different points of the circulatory system were studied chiefly in man (Chaplin \& Mollison, 1953; Doty \& Weil. 1967) and dogs (Baker \& Remington, 1960; Polosa \& Hamilton. 1963). Mollis on (1956) and Polosa \& Hamilton (1963) write that the proportion of cellular elements to plasma is different in different places of the circulatory system. Doty \& Weil (1967) found that the microcirculatory haematocrit values differed from the central haematocrit values in people with a circulatory shock. Chaplin \& Mollis on (1953) demonstrated that in man the total body haematocrit (TBHct) is lower than the venous haematocrit (VHct), the ratio of TBHct to VHct or the so-called $F$-cells being 0.91 . A rmin et al. (1952) examined the TBHct: VHct ratio in rabbits and obtained a mean value of 0.85 .

The dependence of the picture of rabbit blood upon the place in which its sample has been taken and the changes in the composition of blood in the diurnal rhythm have hitherto been given so little attention that the carrying-out of a series of studies covering both these problems seems to have been expedient in view of their importance to comparative physiology and to experimental practice and methods.

\section{MATERIAL AND METHODS}

This investigation has been carried out on 47 mongrel rabbits Oryctolagus cuniculus (Linnaeus, 1758) of both sexes, 6-8 months of age and $3-4.5 \mathrm{~kg}$ in weight. The animals were kept in cages, one in each, on a standard diet.

For experiments the animals were divided into two groups. In Group I (15 males, 3 females) blood samples were taken, by cutting, only from the marginal ear vein every two hour and determinations were made immediately. In Group II (29 males) blood was simultaneously taken from the marginal ear vein (Ve), ventral aorta $(A)$ and posterior vena cava $(V c)$. These rabbits were catheterized prior to 24-hour examination, using a specially adapted heparinized polyethylene catheter. The procedure was performed under general hexobarbital anaesthesia, prolonged, as a rule, with ether. When the animals had recovered from anaesthesia, their blood was sampled, and next it was taken every 4 hours. In order to examine as many rabbits within a day as possible, they were divided into 4 subgroups. Thus, in Subgroup $1(n=7)$ blood was taken every 4 hours from 9 a.m., in Subgroup 2 $(n=8)$ from 10 a.m., in Subgroup $3(n=7)$ from 11 a.m., and in Subgroup $4(n=7)$ from 12. A total of $10 \mathrm{ml}$ of blood was taken from each rabbit in a 24-hour period.

Haemoglobin $(\mathrm{Hb})$ level and haematocrit $(H c t)$ value of biood were determined for all the animals of Group I. The number of erythrocytes (RBC) and that of reticulocytes $(R c t)$ were examined in 15 rabbits of this group. The $\mathrm{Hb}$ level and $\mathrm{Hct}$ value of blood were examined for the rabbits of Group II.

The $\mathrm{Hb}$ level was determined by the cyanmethemoglobin method, using a modified Drabkin's reagent in a "Hemotest" photocolorimeter. The Hct was determined after the blood sample had been centrifuged in a heparinized capillary at 12,000 $\mathrm{rpm}$ (micromethod). The number of $R B C$ was obtained in a Thom-Zeiss counting chamber, using Hayem's fluid, and that of Rct was established as a per mille value of an erythrocytes, stained supravitally with cresyl blue by the Gross-Schwarzkopf method (S chneiber g, 1955) for this purpose.

The results obtained were examined statistically according to Student's $t$ test and analysis of variance, the differences being regarded as statistically significant 
at $p<0.05$ and not significant at $p>0.05$ (Stee $1 \&$ Torrie, 1960; Johan nes, 1968).

\section{RESULTS}

Group I. The number of $R B C$ changed from 4.636 to 3.925 million per cu.mm of blood during a 24-hour period. The highest value was recorded at 3 p.m. and the lowest one at 7 a.m. (Fig. 1). These changes were not statistically significant.
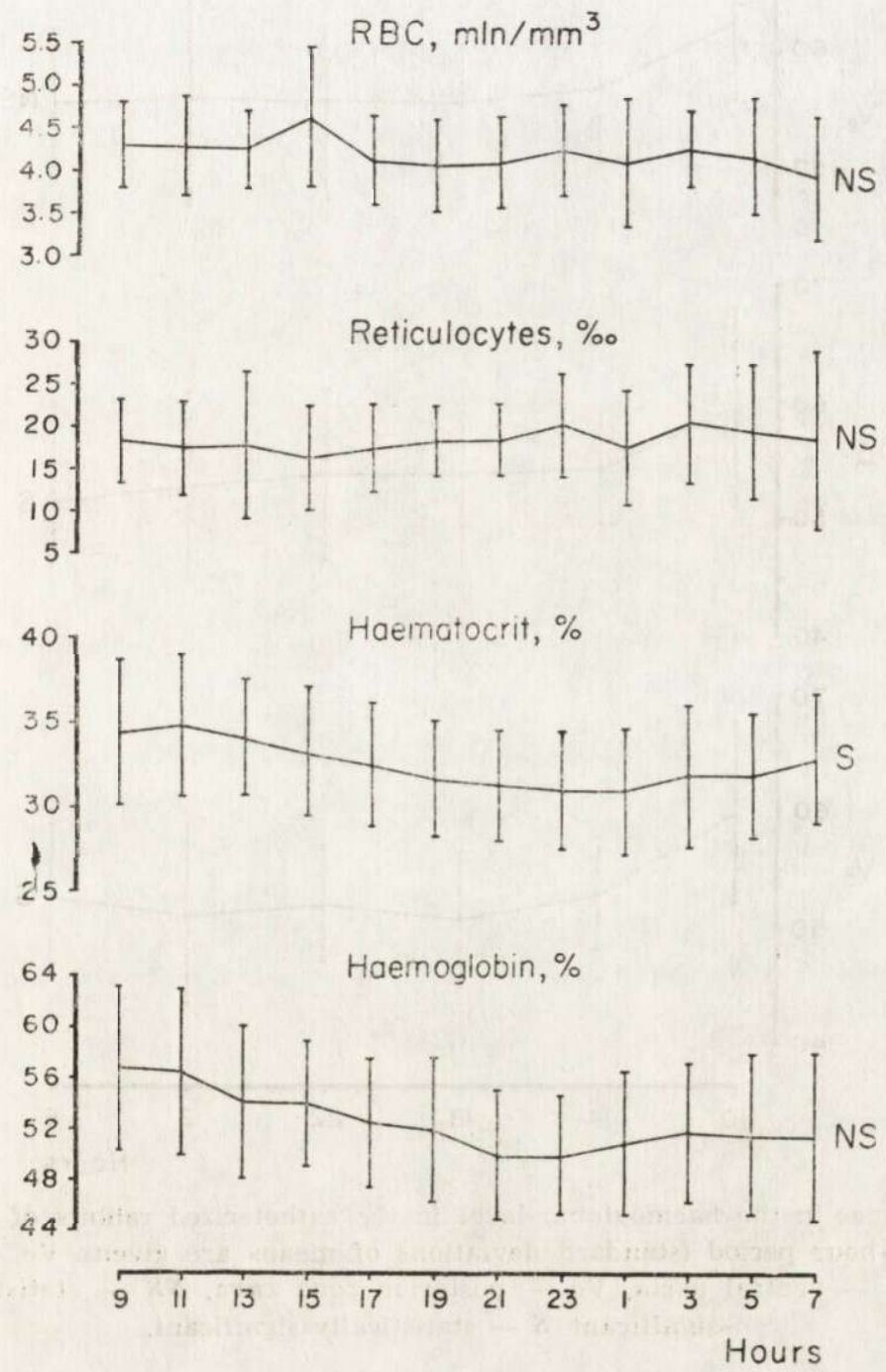

Fig. 1. Changes in the red blood cell system of the rabbit under physiological conditions during a 24-hour period (standard deviations of means are given). NS statistically non-significant, $S-$ statistically significant. 
The number of Rct fluctuated from 16.3 to 20.5 per mille. The lowest value was found at 3 p.m. and the highest at 3 a.m. (Fig. 1). The changes were not significant.

The Hct value ranged from a maximum of 34.8 per cent at 11 a.m. to a minimum of 31.0 per cent between 11 p.m. and 1 a.m., followed
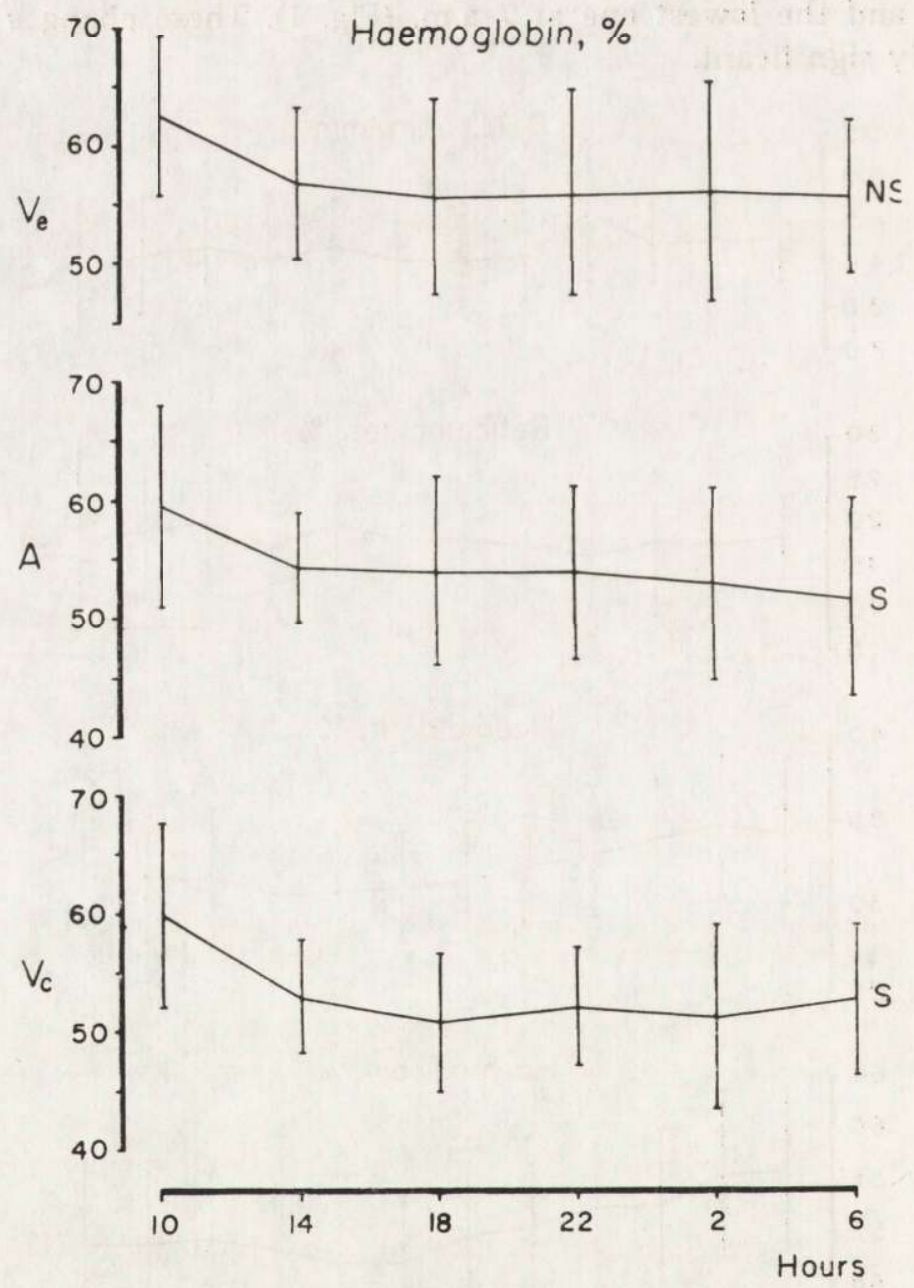

Fig. 2. Changes in the haemoglobin level in the catheterized rabbits of subgroup 2 during a 24-hour period (standard deviations of means are given). Ve - marginal ear vein, A - ventral aorta, Vc - posterior vena cava, NS - statistically non-significant, $S$ - statistically significant.

by a gradual rise in the value of this index (Fig. 1). The changes in the $\mathrm{Hct}$ value during a 24 -hour period were significant.

The $\mathrm{Hb}$ level changed between 56.7 and 49.9 per cent $(9.8-8.8 \mathrm{~g}$ per 
$100 \mathrm{ml}$ of blood). The maximum occurred at 9 a.m., next the value of this index was on the decrease (till 11 p.m.) and later rose non-significantly, without reaching the initial level though (Fig. 1).

Group II. The fluctuations in the $\mathrm{Hb}$ level and $\mathrm{Hct}$ value in a 24-hour period showed similar trends for the animals of all the subgroups. They however differed in absolute values, not allowing a cumulative discussion of the data. This is probably due to the small number of catheterized animals.
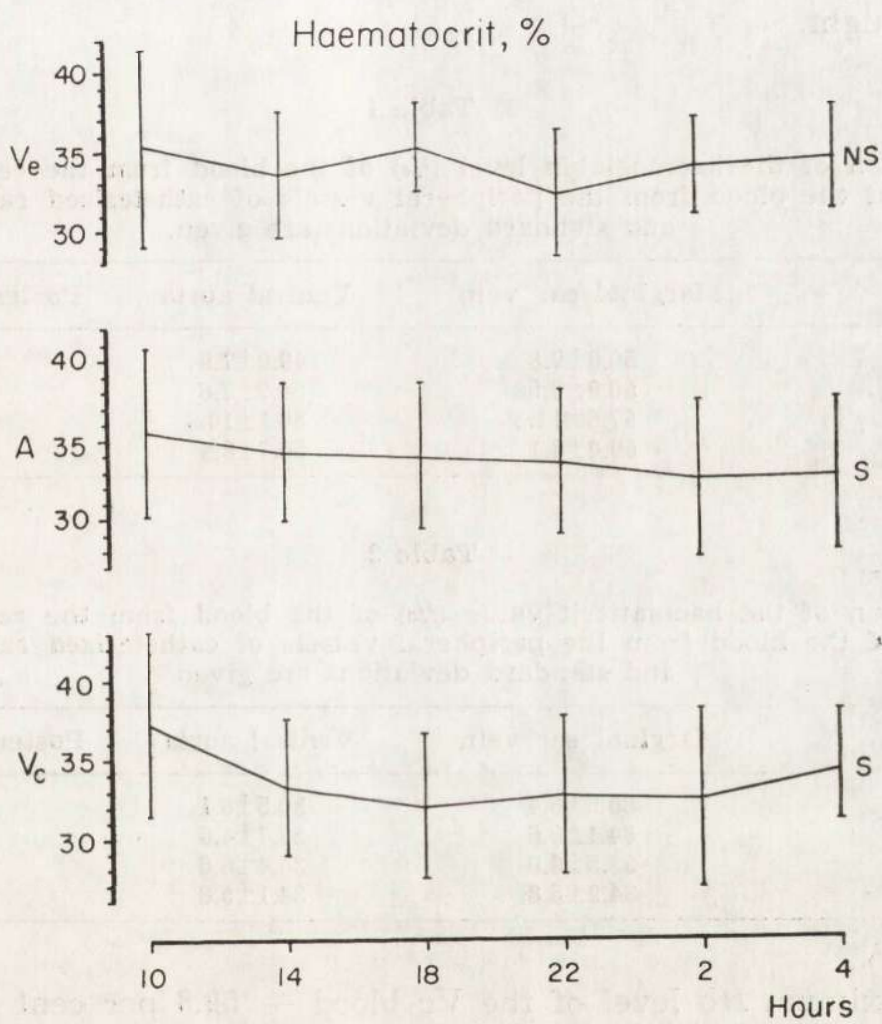

Fig. 3. Changes in the haematocrit value in the catheterized rabbits of subgroup 2 during a 24-hour period (standard deviations of means are given).

The data obtained for Subgroup 2 have been assumed to be illustrative of the changes observed (Figs 2 and 3). Divergencies in diurnal changes and statistical significance between subgroup 2 and the other subgroups will also be discussed.

The highest $\mathrm{Hb}$ level of the $\mathrm{Ve}$ blood of rabbits -62.5 per cent $(10.9 \mathrm{~g}$ per $100 \mathrm{ml}$ ) - was recorded at the first sampling of blood and the 
minimum - 55.5 per cent $(9.7 \mathrm{~g}$ per $100 \mathrm{ml}$ ) early in the morning (Fig. 2). These fluctuations were not significant.

The highest $\mathrm{Hb}$ level of the $A$ blood -59.5 per cent $(10.4 \mathrm{~g}$ per $100 \mathrm{ml})$ was found also in the morning. After a gradual decrease in its value, its minimum - 51.5 per cent $(9.0 \mathrm{~g}$ per $100 \mathrm{ml})$ - was noted before dawn (Fig. 2). The differences were significant. In the rabbits of subgroups 3 and 4 the fluctuations of the $\mathrm{Hb}$ level of the $A$ blood were not significant. In subgroup 4 the minimum was observed as early as 8 p.m., next there was a slight rise in the $\mathrm{Hb}$ level with a renewed downward tendency after midnight.

\section{Table 1}

A comparison of the haemoglobin level $(\%)$ of the blood from the central vessels with that of the blood from the peripheral vessels of catheterized rabbits. Means and standard deviations are given.

\begin{tabular}{lccc}
\hline Subgroup & Marginal ear vein & Ventral aorta & Posterior vena cava \\
\hline $1(\mathrm{n}=7)$ & $50.9 \pm 9.8$ & $49.0 \pm 7.9$ & $46.7 \pm 8.2$ \\
$2(\mathrm{n}=8)$ & $56.9 \pm 6.5$ & $54.2 \pm 7.6$ & $53.1 \pm 6.8$ \\
$3(\mathrm{n}=7)$ & $57.6 \pm 11.3$ & $56.1 \pm 10.3$ & $53.3 \pm 11.0$ \\
$4(\mathrm{n}=7)$ & $59.0 \pm 8.1$ & $56.7 \pm 8.4$ & $55.2 \pm 7.9$ \\
\hline
\end{tabular}

Table 2

A comparison of the haematicrit value $(\%)$ of the blood from the central vessels with that of the blood from the peripheral vessels of catheterized rabbits. Means and standard deviations are given.

\begin{tabular}{cccc}
\hline Subgroup & Marginal ear vein & Ventral aorta & Posterior vena cava \\
\hline $1(\mathrm{n}=7)$ & $30.6 \pm 6.4$ & $30.5 \pm 6.1$ & $29.8 \pm 5.6$ \\
$2(\mathrm{n}=8)$ & $34.1 \pm 3.6$ & $33.7 \pm 4.6$ & $33.6 \pm 4.9$ \\
$3(\mathrm{n}=7)$ & $33.5 \pm 6.9$ & $34.4 \pm 6.6$ & $33.1 \pm 6.9$ \\
$4(\mathrm{n}=7)$ & $34.2 \pm 5.8$ & $34.1 \pm 5.8$ & $33.7 \pm 5.6$ \\
\hline
\end{tabular}

The maximum $\mathrm{Hb}$ level of the $\mathrm{Vc}$ blood -59.8 per cent $(10.5 \mathrm{~g}$ per $100 \mathrm{ml}$ ) - was observed at 10 a.m., next the value of this index decreased to 50.0 per cent $(8.8 \mathrm{~g}$ per $100 \mathrm{ml})$ at $6 \mathrm{p} . \mathrm{m}$., when it began to increase (Fig. 2). Except for subgroups 1 and 3 these fluctuations were statistically significant.

The maximum Hct value of the Ve blood (above 35.0 per cent) occurred at 10 a.m., the minimum (about 32.0 per cent) before midnight (Fig. 3). These changes were not significant, only in subgroup 1 the minimum fell in early morning hours and the diurnal changes were significant.

The highest Hct value of the $A$ blood (over 35.0 per cent) was found at the first taking of blood samples, whereas the lowest values (on the 
average 33.0 per cent) occurred in early morning hours (Fig. 3). In subgroups 1 and 2 the changes were statistically significant.

The maximum $H c t$ value of the $V c$ blood was above 37.0 per cent and it was recorded in the morning. The minimum values - about 32.0 per cent - were noted down in the evening and at night (Fig. 3). The diurnal changes found in the animals of subgroups 2 and 4 were significant.

There were differences in $\mathrm{Hb}$ level between the blood from the peripheral vessels and that from the central vessels (Table 1).

The mean $\mathrm{Hb}$ level of the $\mathrm{Ve}$ blood was higher than that of the $V \mathrm{c}$ blood. The difference was 3.8-4.3 per cent, being significant in subgroups 1,2 and 4 and not significant in subgroup 3.

The mean $\mathrm{Hb}$ level of the $A$ blood was lower than that for the Ve blood (by 1.5-2.7 per cent), but these differences were not statistically significant. Neither were significant the differences in $\mathrm{Hb}$ level between the $A$ and the $V c$ blood ( $1.1-2.8$ per cent).

The Hct values of the Ve blood of rabbits stood close to those for the $A$ and $V c$ samples of blood (Table 2). The differences, ranging from 0.1 to 0.8 per cent, were not significant.

Small, also non-significant, differences $(0.1-1.3$ per cent) were found between the Hct values of the blood from the central vessels (Table 2).

\section{DISCUSSION}

The results presented suggest the existence of diurnal changes in $\mathrm{Hb}$ level, Hct value, $R B C$ count and Rct count in rabbits and also the occurrence of differences in the composition of blood according to the place in which samples have been taken.

As regards the diurnal changes in the Hct value and $\mathrm{Hb}$ level, the results of the present experiments agree with the results obtained by Fox \& Laird (1970) in respect of both the time of day when they occurred and their extent. According to our investigation, the diurnal changes in $H b$ level approximate $1.0 \mathrm{~g}$ per $100 \mathrm{ml}$ at a mean level of $9.4 \mathrm{~g}$ per $100 \mathrm{ml}$, whereas those in Hct value reach 4.0 per cent, its mean being 32.7 per cent. Similar physiological changes have been found in man (Kleiner \& Orten, 1951; Donato \& Strumia, 1952).

The extent of fluctuation in the number of $R B C$ in the rabbits examined was 340,000 per cu.mm at a mean number of 4.24 million per cu.mm. In addition, three peaks of the number of $R B C$ were observed, at noon, at 3 p.m. and 3 a.m., and also a minimum, which occurred in the evening. This is consistent with the data given by Best \& $\mathrm{T}$ a y lor (1971) for man and by Fox \& Laird (1970) for rabbits. 
The extent of changes in the number of Rct was about 4 per mille, the mean number being 18.3 per mille. The largest number of Rct was found after midnight, the smallest one in the afternon. According to $\mathrm{Hal}$ berg \& How ard (1958), in man the largest number of Rct occurs at night. In rats a peak was observed in the evening and a minimum in the night ( $\mathrm{Goldeck} \& \mathrm{St}$ offrege $n, 1952)$. The fact accounting for these differences is the occurrence of activity of the organism in man, rabbits and rats at different times of day.

Catheterized rabbits provided a possibility to investigate the changes in the $\mathrm{Hct}$ value and $\mathrm{Hb}$ level of blood in the peripheral and central vessels. The rabbits of group II appeared to have characteristic maxima and minima of the indices of the $V e, V c$ and $A$ blood at analogous times of day. Moreover, the pictures of diurnal changes in $\mathrm{Hct}$ value and $\mathrm{Hb}$ level (and also in statistical significance) show resemblance to each other, which is only natural, since these indices are correlated.

It may well be that anesthesia and catheterization had some influence on the Hct value. Whereas the diurnal changes in the Hct value of the $V e$ blood were statistically significant for the rabbits of group I, they were not significant for the catheterized animals (Group II).

The haematocrit value depends on the quantities of all the morphotic elements of blood. In addition, the value of this index is loaded with a positive error resulting from the closing of a certain amount of plasma, the so-called trapped plasma, in the column of morphotic elements ( $\mathrm{L}$ e eson \& Reeve, 1951; Chaplin \& Mollisson, 1952).

The difference between the amounts of $H b$ in the $V c$ and $A$ blood is small and not significant, and thus the mean value may be regarded as characteristic of the central blood circulation $(\mathrm{Hb}-\mathrm{C})$. The mean $\mathrm{Hb}$ value of the $\mathrm{Ve}$ blood has been designated as $\mathrm{Hb}-\mathrm{E}$. The $\mathrm{Hb}-\mathrm{C}: \mathrm{Hb}-\mathrm{E}$ ratio has been calculated and it is 0.94 (Subgroups 1 and 2) and 0.95 (Subgroups 3 and 4). This index resembles the $F$-cells index, which is about 0.90 (Armin et al., 1952; Chaplin \& Mollisson, 1953; $\mathrm{Zizza} \& \mathrm{Reeve}, 1958)$. The $F$-cells value is lower, because the mean from the levels of the morphotic elements in all the places of the vascular bed in which the contents of plasma are different in quantity has been used to calculate it ( $\mathrm{Ch}$ a plin, 1956; Polos a \& $\mathrm{Ha}$ miltan, 1963).

The relatively high $\mathrm{Hb}$ level of the $\mathrm{Ve}$ blood is probably associated with intense metabolism in the skin tissue of the rabbit. A confirmation of this supposition may presumably be found in the study by Fried$m$ a n (1960) who injected mice intravenously with erythrocytes labelled with isotopes. The labelled erythrocytes were distributed most quickly 
in the intestinal, muscular and cutaneous blood circulations, or in the regions of the organism characterized by intense metabolism.

\section{REFERENCES}

1. Armin J., Grant R. T., Pels H. \& Reeve E. B., 1952: The plasma cell and blood volumes of albino rabbits as estimated by the dye (T-1824) and 32P marked cell methods. J. Physiol. Lond., 116: 59-73.

2. Baker C. H. \& Remington J. W., 1960: Role of the spleen in determining total body hematocrit. Am. J. Physiol., 198: 906-910.

3. Barański S., Kwarecki K. \& Szmigielski S., 1972a: Wspólczesne zagadnienia chronobiologii ze szczególnym uwzględnieniem aspektów cytologicznych. Med. lot., 38: 15-30.

4. Barański S., Kwarecki K., Ludwicka H., Różyński J. \& Szmigielski S., 1972 b: Wpływ przewlekłego niedotlenienia wysokościowego i zmian czasu oświetlenia na okołodobowy rytm mitotyczny. Med. lot., 38: $79-86$.

5. Best C. H. \& Taylor N. B., 1971: Fizjologiczne podstawy postępowania lekarskiego. Państw. Wyd. Lekar.: 1-768. Warszawa.

6. Bullough W. S., 1947: Mitotic activity in the adult male mouse, Mus musculus $\mathrm{L}$. The diurnal cycles and their relation to walking and sleeping. Proc. Roy. Soc. Lond., B, 135: 212-233.

7. Chaplin H. Jr. \& Mollis on P. L., 1952: Correction for plasma trapped in the red cell column of the hematocrit. Blood, 7: 1227-1238.

8. Chaplin H., Jr \& Mollis on P. L., 1953: The body venous hematocrit ratio; Its constancy over a wide hematocrit range. J. clin. Invest., 32: 1309-1316 .

9. Delaney J. W., 1960: Handbook of haematological and blood transfusion technique. Bulterworth Co: $1-65$. London.

10. Donato R. A. \& Strumia M. M., 1952: An exact method for the chamber count of eosinophils in capillary blood and its application to the study of the diurnal cycle. Blood, 7: 1020-1029.

11. Doty D. B. \& W eil M. H., 1967: Comparision of the microcirculatory and central hematocrit as a measure of circulatory shock. Surg. Gynec. Obstet., 124: $1263-1266$.

12. F ox R. R. \& La ird C. W., 1970: Diurnal variation in rabbits: hematological parameters. Am. J. Physiol., 218: 1609-1613.

13. Friedman J. J., 1960: Distribution of red blood cells between tissues of mouse. Proc. Soc. Biol. Med., 103: 80-83.

14. Goldeck H. \& Stoffregen J., 1952: Die Endogene 24-Std-Periodik der Blutretikulozyten bei der Laboratorium- und Wanderrate. Z. vergl. Physiol., 34: $41-45$.

15. Halberg F. \& Visscher M. B., 1950: Regular diurnal physiological variation in eosinophil levels in five stocks of mice. Proc. Soc. expl. Biol. Med., 75: $846-847$.

16. Halberg F. \& Howard R., 1958: 24 hour periodicity and experimental medicine. Examples and interpretation. Postgrad. Med., 24: 349-358.

17. Harker J., 1958: Diurnal rhythms in the animal kingdom. Biol. Rev., 35: $1-52$. 
18. Johannes A., 1968. Zarys statystyki medycznej. Państw. Zakł. Wyd. Lek. 1-195. Warszawa.

19. Kleiner J. S. \& Orten J. M., 1951: Human biochemistry. Mosby, St. Louis.

20. Kleitma n N., 1949: Biological rhythms and cycles. Physiol. Rev., 29: 1-30.

21. Lees on D. \& Reeve E. B., 1951: The plasma in packed cell column of the hematocrit. J. Physiol., Lond., 115: 129-142.

22. M ollis on P. L., 1956. Blood transfusion in clinical medicine. Blackwell Sci Publ.: 1-39. Oxford.

23. Polos a G. \& Hamilton W. F., 1963: Blood volume and intravascular hematocrit in different vascular beds. Am. J. Physiol., 204: 903-909.

24. Schneiberg K., 1955: Praktyczna metoda równoczesnego liczenia płytek krwi i retikulocytów. Pol. Tyg. Lek., 10: 1414-1415. Warszawa.

25. St e el R. G. D. \& Torrie J. H., 1960: Principles and procedures of statistics with special references of the biological sciences. Mc Graw - Hill: 1-434. New York.

26. $\mathrm{Zizza}$ P. \& Reeve E. B., 1958: Erroneous measurement of plasma volume in the rabbit by T1824. Am. J. Physiol., 194: 522-526.

Accepted, July 10, 1974.

Department of Animal Physiology,

University of Warszawa,

02-089 Warszawa, al. Żwirki i Wigury 93.

Agnieszka REWKIEWICZ-DZIARSKA \& Zofia GŁOSKOWSKA-MORACZEWSKA

\section{RYTM DOBOWY WYBRANYCH WSKAŹNIKÓW CZERWONOKRWINKOWYCH W KRĄŻENIU OSRODKOWYM I OBWODOWYM KROLIKA}

\section{Streszczenie}

Na 47 królikach mieszańcach stwierdzono występowanie cyklicznych zmian w układzie czerwonokrwinkowym, sugerujących istnienie rytmu dobowego. Wahania dobowe wskaźników występują zarówno w krwi naczyń obwodowych jak i ośrodkowych. Poziom hemoglobiny w krwi żyły brzeżnej ucha jest znamiennie wyższy od poziomu hemoglobiny w krwi żyły czczej tylnej. Między wartościami hematokrytu krwi naczyń ośrodkowych i obwodowych nie stwierdzono istotnych różnic. 